\title{
Voldsudsatte kvinner og deres erfaringer med politiet
}

\author{
Af Geir Aas ${ }^{1}$
}

\begin{abstract}
In this article abused women from five Norwegian shelters reveal their experiences with the police. Employees at the shelters also discuss the work of the police from their point of view. The central obstacle between the women and the police lies in the very nature of the criminal law, or at least in how the police perceive the law, and the complex story the women wish to report. The police seem to be primarily interested in basic facts regarding the history of abuse, such as when and in what way the women were physically beaten. These facts often represent less significant parts of a women's story. Mental abuse, which has recently been criminalized in Norway, is not properly included in either the police interview or the police report. Some of the informants also mentioned a lack of continuity in their contact with the police. One of them had to meet four or five different police officers during the long road to trial. Forced to repeat her story to several different agencies, she ultimately wound up talking about the severe abuse she had suffered without showing any emotion. It has been documented that the way in which these women express their tragedy has a significant impact on their perceived credibility. Another common problem typical to their narratives is the time-consuming process from the first police interview until the police reach a conclusion. Some had to wait as much as two years before the case was brought to trial or dismissed. The informants have rather different and contradictory feelings about the legal sanctions brought against their former partners.
\end{abstract}

\section{Innledning}

Artikkelen baserer seg på intervjuer med voldsutsatte kvinner på norske krisesentre i løpet av 2012, som et ledd i en større studie av politiets arbeid med vold i nære relasjoner. Denne studien er bestilt av Justisdepartementet, og inngår som et kunnskapsgrunnlag for en ny stortingsmelding, og dernest en ny handlingsplan fra Regjerningen mot vold i nære relasjoner.

* Title in English: Women exposed to domestic violence and their experiences with the Norwegian police. 
I alt 23 kvinner er intervjuet, hvorav 6 av dem har minoritetsbakgrunn. Følgende krisesentre ble valgt ut: Oslo krisesenter, Betzy krisesenter i Drammen, Bodø krisesenter, Hamar krisesenter og Glåmdal krisesenter i Kongsvinger. Krisesentrene følger de fire utvalgte politidistriktene for studien (Oslo, Søndre Buskerud, Salten og Hedmark). Hensikten med dette utvalget er at det skal representere mangfoldet i Norge i forhold til dimensjonene nord/sør og urbant/ruralt. Det er ikke hvert enkelt distrikt i seg selv som er av interesse for studien, men dets bidrag til helheten.

Nesten alle kvinnene kunne fortelle om langvarig mishandling fra partner, men det var store variasjoner i deres erfaringer med politiet. Noen av kvinnen har oppsiktsvekkende negative erfaringer, hvor grove tjenesteforsømmelser beskrives. Andre forteller om svært positive opplevelser. Denne artikkelen vil fokusere på avstanden og konfliktflatene mellom kvinnene og politiet. Det er særlig her kildene til fornyelse og forbedringer av politiarbeidet ligger. De voldsutsatte gis fiktive navn i fremstillingen. Krisesenteransatte, i alt 14 kvinner, er også intervjuet, og enkelte av dem skal også komme til orde fremover.

I et gruppeintervju med tre brukere av et av krisesentrene brukte jeg offerbegrepet for å omtale voldsutsatte, men fikk denne kommentaren kontant tilbake: Det er vi overhode ikke, vi er ikke ofre - vi er voldsutsatte! Når flere av de voldsutsatte forbinder offerbegrepet med det å være stakkar og svak, er ikke denne motstanden så merkelig. Mange voldsutsatte opplever seg slett ikke som svake, passive og maktesløse. Når man lytter til deres historier blir man slått av hvor utholdende og handlekraftige mange har vært $\mathrm{i}$ å mestre et liv som de fleste andre knapt kan ane tyngden av. Nettopp derfor har selvhjelpsgrupper av voldsutsatte i USA fremstilt seg som «survivors» (Leer-Salvesen 1998, s. 116). Denne artikkelen bruker konsekvent betegnelsen «voldsutsatte».

\section{Forebygging vs. strafferett.}

Artikkelen vil for det meste handle om problemene som oppstår i straffesakssporet - eller mer presist konfliktforholdene i møtet mellom den strafferettslige rammen og voldsutsatte som kommer til politiet med en lengre mishandlingshistorie. Politiet kan imidlertid jobbe på flere plan overfor voldsutsatte. Et sentralt spor er det tverrfaglige, hvor politiet jobber i samarbeid med andre aktører, som barnevernet, krisesentre, behandlingsinstitusjoner, $\mathrm{NAV}^{2}$ etc., og forsøker å oppnå hjelpetiltak for de involverte i familievolden. Et interessant eksempel på det ble gitt av en politietterforsker som fortalte meg at hun nærmest hadde presset NAV til å tildele en voldsutsatt kvinne en bolig som var plassert høyere opp i boligblokken hvor kvinnen bodde. Problemet var at kvinnen hadde en bolig på bak- 
keplanet, tilgjengelig for eksmannens stadige plaging av henne. Med en bolig plassert høyere opp, kunne ikke mannen lenger skride over balkongen hennes. Denne fortellingen vitner om en enkel, men likefullt svært effektiv måte som politiet kan hjelpe volds- og trusselutsatte. Politiet kan åpenbart bruke sin autoritet på ulike måter, og politiet spiller ikke bare rollen som lovens håndhever i arbeidet med familievold, men også rollen som sosialkurator, krisehåndterer, mekler, veileder og sjelesørger (Aas 2009).

Straffesakssporet begrunnes på flere måter, og da særlig gjennom de allmennpreventive argumentene. Samtidig viser dette sporet seg ofte å være en blindgate når 60-70 prosent av alle familievoldssakene henlegges. ${ }^{3}$ Politiets muligheter til å forebygge nye overgrep blir dermed vel så viktig som å reagere strafferettslig i etterkant. Grøvdal finner at politiets fokus på rettsliggjøring av familievold ligger til hinder for politiets fremste oppgave som handler om å forebygge nye lovbrudd (Grøvdal 2012, s. 233). Dette samsvarer også med mitt eget materiale, for eksempel når det gjelder fraværet av politibistand når voldsutsatte har fătt tilhold på krisesenteret. Det hender brukerne av krisesentrene trenger politieskorte for å hente nødvendige eiendeler i sitt eget hjem (som for eksempel medisiner, bankkort og pass). Dette er åpenbart en risikosituasjon for kvinnen, og hun tør gjerne ikke å gjøre dette alene. Det er bare politiet som kan sørge for at dette ærendet kan foregå på en trygg og sikker måte. I Oslo har krisesenteret derimot fått høre av politiet at de ikke er noen taxisentral. Hadde politiet i større grad vært orientert mot forebyggelse av nye overgrep, hadde de neppe svart på den måten.

\section{Strafferett mot sammensatte livshistorier}

Det problematiske møtet mellom politiet og voldsutsatte kvinner er dokumentert i en rekke studier tidligere (jf. Lund 1992, Jacobsen 1996, Hoyle 1998, Lundberg 2001, Skjørten 2002, Aas 2009, Grøvdal 2012). Grøvdal finner at de negative møtene som hennes informanter hadde med politiet ikke nødvendigvis skyldes dårlige holdninger hos politibetjenter, men selve avstanden mellom den virkeligheten som kvinnene lever i og politiets arbeidssituasjon (Grøvdal 2012). Mer levende og presist enn Ingrids fortelling kan denne avstanden knapt beskrives. Hun sier dette til meg:

... historiene våres - hvis vi skal fortelle dem om igjen - de kan bli annerledes - det kommer an på hvor i situasjonen du er akkurat nå - om du er langt nede - hva opplevde du i dag, hva opplevde du i går - så er det så utrolig vanskelig å ... kan ikke si at 10. oktober (årstall) så skjedde det - tidsperspektiv - de flyter - for det har vært et rent helvete i 20 år ... skjønner du hva jeg mener? ... derfor kan du ikke forholde deg til alle de datoene - og det er så viktig i forhold til 
hendelsene de skal skrive rapporter om - ja - når skjedde det? - nei, det husker jeg ikke - skal vi se - ungene var 3-4 år og det kan være i (årstall) ... kanskje vi oppfattes som litt upresise, men det er sånn svada de datoene og de greiene - det er ikke det vi klarer å fokusere på. Vi klarer å fokusere på at vi må bort fra det rene helvete vi har bodd i - for det er snakk om liv og død altså.

Politiet er avhengig av nærmest eksakte tidsangivelser for når mishandlingen fant sted, og nøyaktige beskrivelser av mishandlingen. Dette er noe voldsutsatte gjerne ikke husker spesielt godt eller finner særlig betydningsfullt. Politiets detaljfokus blir av Frida fremstilt slik:

Det ble mye å gå igjennom. Så er det jo kanskje noen ganger man kanskje følte at politiet er veldig opptatt av detaljer - hvordan skjedde det? - og hvor var du da? - og hvordan reagerte du? Det liksom var - nesten ... hvor i rommet var du? - hvor mange skritt tok du? - man husker jo ikke det.

Det er en helhetserfaring, ofte et samliv preget av en undertrykkende og destruktiv partner over mange år, som voldsutsatte kommer til politiet med - ikke først og fremst enkelthendelser. Han ville bare høre om episoder med vold, forteller Adina fra sitt politiavhør. Hvis politiet utelukkende retter sitt blikk mot konkrete enkeltepisoder så risikerer man bare å se enkelttrær, men taper bildet av hele skogen for å bruke en velkjent metafor.

Hva kan politiet gjøre for å minske noe av denne avstanden som flere av kvinnene forteller om? Politiet bør tydeliggjøre sin rolle bedre, forklarer en av de krisesenteransatte. En samtale med politiet om straffbare overgrep er en annen type samtale enn hva andre profesjonelle aktører vil være interessert i. Politiet kan ikke sies å være en aktør først og fremst for offerstøtte, selv om mange politibetjenter kan gjøre en utmerket jobb i ivaretakelsen av den enkelte. I etterforskningsfasen arbeider politiet hovedsakelig med beviser og etterprøvbare opplysninger, og skal orientere seg mot objektivitet og rettssikkerhet. Politiet er som regel avhengige av et nokså solid bevismateriale for å kunne reise tiltale mot den personen som anklagene retter seg mot.

Derfor må politiet være nøye med å forklare på en tydelig måte hva som er politiets rolle, hva politiet kan hjelpe voldsutsatte med, hvordan avhøret skal legges opp, hvorfor de er avhengige av bestemte fakta, kravene til bevis for å kunne reise tiltale etc. Dette bør selvsagt formidles på en pedagogisk og omsorgsfull måte - som den gode tannlegen kommuniserer med pasienten sin. Tannlegemetaforen interesserer Linnea, som ble møtt av politiet på en nokså brysk og konfronterende måte: 
Ja, jeg skjønner hva du mener - hvis du er hos tannlegen så forteller tannlegen hele tiden hva han har tenkt til å gjøre - Jeg skyter inn: ja, nettopp det, og dette kommer til å gjøre vondt - og hun responderer; ja, det hadde blitt en mye bedre samtale vil jeg tro, hvis han hadde klart å kommunisere på den måten der - da hadde jeg følt meg tryggere.

I innledningen på politiavhøret kommer straffesaksproblemet nokså brutalt og skremmende til uttrykk, hvor politiet skal informere om straffeprosessens krav til vitneplikten. Da skal politiet også informere om konsekvensene av å forklare seg falskt, noe som åpenbart er egnet til å skremme den voldsutsatte. Hvis ikke politiet kommuniserer disse reglene på en god måte, kan kommunikasjonen utvikle seg i gal retning fra første stund. Dette blir utdypet av en de krisesenteransatte som har vært med brukerne av krisesenteret i politiavhør:

Jeg syns at de som foretar avhørene - når de bruker litt tid i forkant og klarer å forklare hva som skal skje - så blir det et mye bedre avhør (...) Man gjør det korrekt, men man starter med å si at dersom du ikke forteller sannheten nå - da risikerer du å bli straffeforfulgt! Når du starter der så blir de jo veldig redde! Er det jeg som er mistenkt? (kan den voldsutsatte tenke).

En gjennomtenkt avhørsprosess blir derfor nødvendig, og den bør helst være faseinndelt (Bjerknes og Hoff Johansen 2009). I forkant av avhøret bør politietterforskeren om mulig forberede seg på den voldsutsattes historie. (Det er mulig hvis hun har snakket med politiet tidligere.) Når voldsutsatte kommer til politiet, bør det brukes tid på kontaktetablering og en innledende samtale. Det er i denne fasen etterforskeren bør forklare hva et politiavhør handler om, hva som er avhørets mål og hvordan det skal legges opp. Dernest bør den som skal avhøres, iht. påtaleinstruksens $\S 8-2$ og 8-6, få muligheten til å gi en fri og sammenhengende forklaring. Det betyr å få anledning til å fortelle fritt fra sin voldshistorie som gjerne har pågått over lengre tid. Først nå blir det aktuelt for etterforskeren å stille oppklarende spørsmål til historien. En slik avhørsprosess har et potensial til å ivareta voldsutsatte på en taktfull og skånsom måte, hvor de mer detaljorienterte spørsmålene som er nødvendige for straffesaken kommer etter at hele historien er blitt fortalt.

\section{Psykisk mishandling som ikke fanges opp}

Mye av hensikten med å innføre en egen familievoldsbestemmelse i Norge i 2005 (straffelovens $\S 219^{4}$ ) var å fange opp helheten og kompleksiteten i et mishandlingsforhold, ikke bare de enkelte og konkrete hendelsene. I Ot.prp. nr. 113 fremheves det at det er «viktig at vold og trusler ikke blir sett på som enkeltstående handlinger» (Justis- og Politidepartement 2004-2005, s. 40-41). Da er det et tan- 
kekors at politiet til tider ikke klarer å fange opp denne helheten i avhøret. Helheten $\mathrm{i}$ et mishandlingsforhold handler langt fra bare om de fysiske overgrepene. Frida forklarer dette slik:

Når du møter politiet er det jo veldig det der - den volden - den fysiske volden du har blitt utsatt for er kanskje det mest fokus på da - den psykiske volden - den angsten, den redselen man har hele tiden fordi den andre personen har så kontroll over hodet ditt på en måte - den er nesten verre. Det er den man lever med hele livet - ikke blåmerker - den psykiske delen som kanskje var den verste og som er vanskelig å forstå selv også. Men som de veldig forstod her på krisesenteret. Der tror jeg politiet kan hente veldig mye.

Flere av de voldsutsatte kan i tråd med Frida fortelle at det er den psykiske delen av et mishandlingsforhold som er den tyngste, men politiet er mest opptatt av den fysiske. Psykisk mishandling i nære relasjoner er i seg selv kriminalisert i § 219 gjennom ordlyden «på annen måte krenke» (Justis- og Politidepartement 20042005, s. 40). Innenfor en strafferettslig ramme er det imidlertid åpenbart at det er den fysiske volden som får forrang, og det har noe med bevissituasjonen å gjøre. Fysisk vold, spesielt den som har medført skade, er langt lettere å dokumentere enn den psykiske. Psykisk mishandling kan være langt mer diffus, udefinerbar og usynlig, der politiet ofte blir henvist til en vurdering av ord mot ord. Dessuten kan det hende at det kreves mye psykisk mishandling før politiet vil bringe anmeldelsen frem til tiltale. Gabrielle forteller dette om sin erfaring med politiet:

... og min sak angående overgrep med vold - den var også henlagt ... det var litt for lite vold mot meg. De mente at hvis han har slått meg eller kanskje skadet kroppen min så går det helt greit, men det var litt for lite - at han har drukket alkohol og ble funnet i gata av to politimenn som har kommet med han hjem, han har ringt folk og ment at jeg har elskere, at jeg har sex i banken og på skattekontoret, åpnet alle mine brev, epost, telefon - han gikk etter meg og ropte at jeg er ... og andre ting - og ringte overalt til mine kunder jeg hadde via (firmanavn) - så jeg ville ta livet mitt (...) De forstår at jeg hadde det dårlig - de forstår det, men det var lite - så jeg lurer på hva betyr lite - hvor mye? - vi har ikke sånne mål - vi måler ikke psykisk vold i form av milliliter eller centimeter ...

Problemene ved å avgjøre når destruktiv oppførsel går over til straffbar psykisk vold, lå til grunn for motstanden blant flere av høringsinstansene mot å inkludere den psykiske mishandlingen $\mathrm{i}$ den nye straffebestemmelsen mot familievold (Justis- og Politidepartement 2004-2005, s. 38). Nora har nok erfart noe av dette når hun refererer slik fra sine politibesøk som følge av et samliv med en partner som plagde henne systematisk uten å bruke fysisk vold: 
Mitt inntrykk er jo at hvis det er blod og gørr nok - så får du hjelp - er det bare psykisk - bare truing - bare sjikanering - bare en psykopat som herjer med deg uten å slå deg så er det ikke så vigtig ... Du har ingen ting å vise til ikke sant - du har ikke en knekt arm - du har ikke en blåklokke å vise til.

Det er nettopp slike erfaringer som får den amerikanske sosiologen Loseke til å reise følgende treffende spørsmål: «Do women need to show their bruises and broken bones to receive public sympathy?» (Loseke 1992, s. 10). Loseke gjør for øvrig en større analyse av hvordan vold mot kvinner har blitt presentert for opinionen. Hennes egne begreper på dette er også deler av tittelen på boken: «the social construction of wife abuse». Vold mot kvinner har i følge Loseke blitt systematisk definert og beskrevet gjennom de mest dramatiske bildene, og det er særlig blod og gørr (som Nora sier det) som det rådende og offisielle bildet av vold $\mathrm{i}$ nære relasjoner handler om. Når fremstillingen av kvinnemishandling blir ribbet for nyanser, og kompleksiteten reduseres til forenklede kjennetegn, er det fare for at praktikerne vil være utstyrt med et endimensjonalt kart $\mathrm{i}$ håndteringen av denne virkeligheten. Kvinner som ikke kan fremstille seg i tråd med konstruksjonen kan fort bli plassert i kategorien «not battered woman» (Loseke 1992, s. 4).

Politiets manglende interesse for psykisk mishandling blir dokumentert i flere tidligere studier. Eriksson har intervjuet svenske politiadvokater som opererte med forestillinger om «en ordentlig misshandel» og «en misshandel med kvalitet», i vurderingene av å reise tiltale. Kvalitetskriteriene dreide seg om fysiske skader, og uten slike håndfaste bevis ble man stående igjen med «ord mot ord», og dermed en problematisk troverdighetsvurdering av partene (Eriksson 1995, s. 140, 141). Lundberg reiser spørsmålet «Är alla skador like mycket 'värda'?», og han finner at politiet opererer med et slags bevishierarki hvor fysiske skader har åpenbar forrang (Lundberg 2001, s. 109). Hoyle viser til « (...) the very clumsiness of the criminal justice system as a tool for solving domestic disputes» (Hoyle 1998. s. 204). Den strafferettslige logikken blir dikotomisk og sort/hvittpreget - med en orientering rundt lovbrudd/ikke lovbrudd, straff/ ingen reaksjon etc. Nyansene har små kår i denne strukturen.

Likevel kan det gode politiavhøret fange inn den psykiske mishandlingen gjennom samtaler om hvordan den utsatte ble kuet, trakassert og frihetskrenket men da kreves kunnskap om denne typen vold og dens karakter. Flere av mine informanter opplever imidlertid politiet som langt fra kunnskapsrike på dette feltet. Ingrid forklarer betydningen av å stille de riktige spørsmålene til utsatte for langvarig mishandling på denne måten: 
Hva skal vi tørre å fortelle? - for det er en utrolig høy terskel du skal gå over før vi begynner å fortelle - vi begynner jo i det små på en måte og håper at den andre personen kan stille de riktige spørsmål. Hvis du er heldig å møte en person som stiller de riktige spørsmål så er det jo lettere for da skjønner du at det er en som skjønner hva jeg snakker om.

\section{Fraværet av kontinuitet og progresjon i straffesaken}

Flere av de voldsutsatte forteller om fravær av kontakt med politiet etter avhøret. Frida møtte 4-5 forskjellige politibetjenter i sin straffesak. Så plutselig møtte man en ny person $d a$ - sier hun, og forteller om sin opplevelse av dette på denne måten:

Det er ikke ålreit - det er veldig frustrerende ... fordi at jeg føler at min historie er viktig - og det er et stort skritt å anmelde - hadde veldig respekt for politiet - også da møte en ny person hele tiden - og fortelle historien om igjen - og detaljer om igjen - å gud forklarte jeg det riktig nå (tenkte hun) - så kanskje det ble annerledes enn forrige gang. (...) Så er det å helst møte de samme personene - det er veldig viktig - sånn som jeg da - måtte jo fortelle historien min på krisesenteret, til barnevernet, så skal du fortelle det til fire-fem politibetjenter - så skal du helst gå til en psykolog og fortelle det der også.

Når man må gjenta sin historie gang på gang, kan historien bli gradvis mer fremmed for en. Frida forteller at hun opplevede seg selv som kald etter hvert som hun fortalte sin historie stadig på nytt. Ved gjentatte fremstillinger mister man på en måte noe av følelsene til sin smertefulle erfaring, og dette kommenterer hun på en interessant måte slik: Til slutt blir man så utmattet på en måte - når du kommer til politiet så tenker jeg - nå burde jeg egentlig kanskje sitte og grine. Fraværet av tårer kan kanskje rokke ved hennes offerstatus. Hun opptrer ikke på en måte som mange forventer av et «offer».

En doktorgradsstudie fra 2007 kan bekrefte nettopp gråtens betydning, hvor det påvises at måten voldtektsutsatte forteller om overgrepet på har betydning for vurderingen av hennes troverdighet (Ottesen og Bollingmo 2007). Forskerne hadde engasjert profesjonelle skuespillere til å fortelle om voldtektshendelsen som de liksom skulle vært utsatt for. Fortellingene ble fremført på tre ulike måter: med gråt, følelsesnøytralitet og oppstemthet. Fortellingene ble tatt opp på video og vist frem til politietterforskere, dommere og studenter. Studien konkluderer med at en gråtkvalt fortelling ble av politiet vurdert som mer troverdig enn ved de andre følelsesuttrykkene.

Fraværet av kontinuitet henger sammen med et annet velkjent problem når det gjelder politiets håndtering av familievolden, og det handler om tidsbruken $\mathrm{i}$ straffesaksarbeidet. Frida opplevde at det tok to år fra anmeldelse til dom. Det gjorde Vilde også, men hun nådde ikke lenger frem enn til en henleggelse på be- 
visets stilling av anmeldelsen sin, og hun beskriver sitt møte med politiet på denne måten:

Han som tok i mot anmeldelsen var usedvanlig hyggelig. Han tok jo dette kjempealvorlig - jeg følte virkelig at denne mannen tror på meg altså ... så det var en god følelse, men når du da har godkjent anmeldelsen din - så er det ikke noe mer - det er ingen ting.

Dette «ingenting» handler om fravær av kontakt med politiet etter anmeldelsen, og hun følte det som forferdelig at hun ikke hadde noe med sin egen sak å gjøre lenger. Når hun ikke hørte noe mer fra politiet opplevde hun også at politiet ikke respekterte henne. Til tross for en god mottakelse hos politiet, gikk hun over til å føle seg betydningsløs. Hun forklarer selv: Når du kommer til politiet er du hovedpersonen i 3 timer - så er du en ikke-person. Også på dette punktet finner jeg et tydelig samsvar med Grøvdals forskning, hvor flere av de voldsutsatte i hennes studie opplevde politiet på denne måten: «Fra å være godt mottatt, lyttet til, ivaretatt og behandlet med respekt, gikk flere av dem over til å føle seg helt betydningsløse» (Grøvdal 2011, s. 263).

Vilde har interessante forslag til forbedringer av politiarbeidet når det gjelder tidsaspektet:

Dette handler veldig mye om hva politiet sier til deg når du kommer og anmelder. Hvis de hadde sagt til meg - vet du hva, vi har en gjennomsnitts behandlingstid på 9 måneder - så hadde den ventetiden fortonet seg helt annerledes - det er beklagelig, men sånn er det. For da går du ikke og venter på den måten. Da vet du det. Men når du ikke vet det og du har en forventning om at (...) så er det jo sånn som du sier at man føler at man blir mistrodd (...) hvis man blir orientert om at det er sånn det må være, og at grunnen til at det er sånn er fordi sånn og sånn - så tror jeg mennesker håndterer det ganske greit.

På samme måte som nødvendigheten av å informere om politirollen, avhøret og hva en straffesak innebærer blir det også viktig å gi voldsutsatte realistiske perspektiver over tidsbruken i straffesaksarbeidet. Vilde oppnådde ikke annet enn en henleggelse av saken sin, og hun mener også at hun burde vært informert om at relativt få saker som omhandler vold i nære relasjoner fører frem til tiltale og dom. Hvis politiet ikke formidler straffesakens fremtidsutsikter står man i fare for å holde folk for narr ved å bidra til urealistiske forventninger til sakens resultat. Ved det første avhøret kan man informere om disse spørsmålene på en mer generell måte, uten å måtte ta presis stilling til den aktuelle saken og dens videre skjebne. Det har politiet begrenset innsyn i på anmeldelsestidspunktet, men vet mer om det generelle bildet. 
Bistandsadvokatene har en viktig rolle i dette informasjonsarbeidet, og utsatte for alvorlig mishandling har etter straffeprosessloven rett til advokathjelp på offentlig bekostning. En bistandsadvokat skal være et slags bindeledd mellom politiet og voldsutsatte, og tjene de voldsutsattes interesser gjennom hele prosessen. Disse advokatene er imidlertid nokså fraværende i kvinnenes fortellinger, og blant krisesenterlederne er det ulike erfaringer for hvor tilgjengelige bistandsandsadvokatene er for de voldsutsatte. I denne sammenheng bør det nevnes at voldsutsatte også har rett til å ha med seg en tillitsperson under politiavhøret. En venninne, et familiemedlem eller en krisesenteransatt, som ikke har noen rolle i saken, kan være en verdifull medhjelper overfor en som befinner seg i krise og kanskje av den grunn ikke er helt mottakelig for informasjon.

\section{Forventninger og misnøye med rettssystemet.}

Flere studier har dokumentert motstand fra voldsutsatte kvinner når det kommer til anmeldelse og straffeforfølgning av partneren hennes. Mange kvinner ønsker ikke mannen sin straffet tross lengre tids alvorlig mishandling (se Lund, 1992, Hoyle 1998, Aas 2009, Grøvdal 2011). Politiet har tradisjonelt vært tilbakeholdne med å bruke bestemmelsene om offentlig påtale i denne typen straffesaker (Aas 2009). Politiets anmeldelsesplikt er imidlertid blitt påminnet og innskjerpet ved flere anledninger, og da særlig føringene fra Riksadvokaten i et eget rundskriv fra 2009. Her presiseres det at «det er ikke akseptabelt å behandle meldinger om vold i familien som ‘husbråk' som etter utrykning anses 'oppgjort på stedet'(...)». Familievold skal med andre ord anmeldes for videre etterforskning. Spørsmålet om anmeldelse blir imidlertid vurdert på høyst ulike måter av kvinnene i dette intervjumaterialet. Sofie argumenterer for at politiet ikke skal ta hensyn til den voldsutsattes uttalte ønske om å la være å straffeforfølge mannen. I stedet er det viktig at politiet er i stand til å tolke kvinnen og hennes situasjon på riktig måte, mener hun - og utdyper:

Da må man skjønne problematikken - kvinnen står og sier - vær så snill - ikke anmeld! - da må vedkommende tenke at det er klart hun sier det, for hun vet at det blir et helvete etterpå. Altså livet hennes står i fare - da må man få inn et annet system rundt denne kvinnen - man skriver at kvinnen ikke ønsker å anmelde - hva ligger bak? - da må noen andre begynne å plukke opp. Det betyr at flere etater må begynne å jobbe sammen - ikke bare politiet for seg, men de må trekke inn etater - det må være mye større samarbeid.

En anmeldelse alene er langt i fra nok for Sofie når det gjelder å få hjelp ut av et mishandlingsmønster. Hun ser det som helt avgjørende at politiet spiller på lag 
med andre aktører. Linnea opplevde derimot politiets anmeldelsesplikt som vanskelig med disse ordene:

Det kan jo føles som om kontrollen blir tatt litt i fra deg da - nå er det på en måte ikke jeg som eier den historien lenger - det kjente jeg egentlig på hele veien - en vil jo veldig gjerne styre selv. Det er jo veldig personlig og veldig intimt på en måte ... sårbart - og noen andre skal på en måte styre hva som skjer videre - det var ikke behagelig det.

Ubehaget ved å miste kontrollen over anmeldelsen er slett ikke ubegrunnet. En straffesak kan fort virke konflikteskalerende og gå direkte utover den utsatte. Når jeg spør Ida om hvordan hun opplever at politiet er trukket inn i hennes konflikt med eksmannen hennes, resonnerer hun på denne måten:

... et dårligere samarbeid med faren til barna mine blir enda dårligere - det er jo det jeg forventer (...) hvis han hører at jeg har gjort det sånn at politiet er innblandet, og skal avhøre han og sånne ting - jeg vet at det går utover meg.

Et viktig spørsmål blir dermed hvordan politiet kan trygge voldsutsatte som har grunn til å frykte at en anmeldelse vil forverre situasjonen hennes. Politiets kontakt med hjelpeaktører som krisesenter, barnevern og behandlingsapparatet blir i denne forbindelse nødvendig. Frida setter ord på dette slik:

Hvis politiet hadde anmeldt han - og hvor skal jeg være i mellomtida? For politiet kommer til å gå. Blir jeg plassert på et krisesenter? - hva skjer med meg? - han vet at politiet anmelder han fordi han har slått meg - så kommer han til å bli enda mer - kommer til å bli dritforbanna.

Det er interessante motsetninger i intervjumaterialet når det gjelder forventninger til rettssystemet og synet på straffereaksjoner. Flere av kvinnene uttrykker skuffelse over manglende grensesetting overfor ekspartneren. Nora forteller at eksmannen hennes kunne fortsette å plage henne: Du har anmeldt - du har kommet deg ut av forholdet - har på en måte gjort alt det du skal-og enda så tar det ikke slutt - han får lov til å fortsette. Fatima uttrykker med resignasjon og skuffelse at - de beskytta meg, men de gjorde ingenting mot han da. Hvis de hadde stoppet han - da hadde han loert seg fra den situasjonen - og det er frykten for hva han kan gjøre mot andre kvinner som opptar Fatima på intervjutidspunktet.

Når det gjelder straffereaksjonene kommer imidlertid ambivalente syn til uttrykk. Maja oppfatter dommen (ubetinget fengselsstraff og erstatningskrav) mot eksmannen som mild, men hevder at det ikke ligger noe - ondskapsfullt - bak denne tanken - det handler om at du som menneske skal ta konsekvensene av det 
$d u$ har gjort, slår hun fast. Anna gir også uttrykk for tvetydige motiver. Først sier hun at - jeg gjør ikke dette for hevn - men nå har jeg begynt å tenke - faen heller - hun vil gjerne ha en dom på han nå. Hennes motiver for å anmelde handler først og fremst om at hun skal bli trodd, slik at hennes tidligere nettverk av venner og bekjente skal forstå. Hun tolker en dom mot eksmannen på denne måten: skulle det ikke bli dom så får han rett - da er jeg nok en gang den hysteriske kvinnen. Her blir det straffens symbolske og mindre uttalte sider som blir fremtredende. Straffen har en egen evne til å plassere skyld, og vise sondringen mellom rett og galt på en tydelig måte (Aubert 1972).

Vildes hovedanliggende bak anmeldelsen var å si i fra. Da hun ble spurt av politiet om hun ønsket gjerningsmannen straffet hadde hun svart politiet på denne måten: Det viktigste for meg var jo å si fra - hvis det at jeg sier fra til dere fører til konsekvenser for han - så får det jo så vare - det er jo ikke opp til meg. Men etter hvert som tiden går, når overgrepene og anmeldelsestidspunktet blir mer og mer fortid for henne, karakteriserer hun straffesaken som et - forferdelig dilem$m a$. Nå som sinnet og sorgen har dempet seg, har hun begynt å tenke på om det eksmannen gjorde mot henne er så alvorlig at han fortjener flere år bak murene. Samvittighetskonflikten hun befinner seg i kommer til uttrykk i spørsmålet hun stiller seg selv: Kan jeg leve med å sette han i fengsel? Hun føler at hun har mange motstridende hensyn å forholde seg til nå - hensynet til ekspartneren og hans familie på den ene siden, og hensynet til sine barn og sin egen familie som forventer straff på den andre siden.

Denne konflikten tærer tydelig på Vilde, og i en e-post avslører hun: «Jeg befinner meg i et enormt moralsk, etisk og medmenneskelig dilemma». Det ser ut til at Skjørtens tvil om « (...) hvem av partene som straffes hardest i møte med strafferettssystemet» (Skjørten 2002, s. 153), er godt dekkende for Vildes erfaringer. Derfor har hun begynt å tenke på en alternativ reaksjonsform for vold i nære relasjoner, der partene møtes for å snakke ut om sine opplevelser av det som har skjedd. Hun sier: Kan vi prøve å gjøre det - kan vi rett og slett sette oss ned rundt et bord - og så kan jeg få lov til å fortelle - så kan han få lov til å fortelle - og hun ser for seg følgende mål for samtalen: Jeg kunne ønske at han kunne si unnskyld til sønnen min jeg - men det måtte vare en beklagelse som var fundert på en viss forståelse - ikke bare et ord. I «Handlingsplan mot vold i nære relasjoner 2008-2011 - Vendepunkt» tar myndighetene til orde for å opprette et «sivilt spor» der «ofre for vold i nære relasjoner skal gis tilbud om tilrettelagte samtaler med voldsutøver (restorative justice)» (Justis- og politidepartementet 2008, s. 11). Myndighetene erkjenner samtidig at det ordinære reaksjonsapparatet ikke er tilstrekkelig: 
«Forestillingen om rettsapparatets `helende effekt', særlig i saker der det er en nær relasjon mellom offer og overgriper, må trolig dempes. Vi vil derfor, i tillegg til rettsapparatets behandling av de straffbare forhold, åpne for å søke nye veier for å bistå den som har vært utsatt» (Justis- og politidepartementet 2008, s. 11).

Vilde peker på noen grunnleggende verdier ved RJ-prosessen - hvor dialog mellom partene skal skape en felles forståelse av hva som har skjedd, som et grunnlag for forsoning og oppriktig anger. Det er imidlertid noen åpenbare svakheter ved RJ-modellen når det gjelder vold i nære relasjoner. Faren for nye overgrep er så avgjort til stede, spesielt hvis voldsutøver ikke tar ansvaret for voldsbruken, men fortsetter benektelse og bagatellisering av overgrepene. Her ligger det en viktig, men vanskelig utfordring for konfliktmeglerne. Samtidig foreligger det også velkjente skyggesider ved den ordinære straffesaksprosessen, når voldsutsatte opplever både avmakt og fremmedgjøring i forhold til sin egen sak, og en reduseres til et vitne uten særlig påvirkning på sakens gang. «Offeret har tapt sin sak til staten» - påstår Christie i den internasjonalt kjente artikkelen om «Konflikt som eiendom» (Christie 1977, s. 116).

\section{Noter}

1. Geir Aas er utdannet sosiolog, og har en doktorgrad i kriminologi/rettssosiologi fra Universitetet i Oslo. Han er ansatt som førsteamanuensis ved Politihøgskolen i Oslo, med politiforskning og undervisning som primæroppgaver. Han har studert politiets arbeid med vold i nære relasjoner gjennom to store forskningsprosjekter siden 2005. i tillegg har han gjort forskning på befolkningens trygghetsfølelse i det offentlige rom.

2. Arbeids- og velferdsetaten.

3. I søk i PAL for STRASAK viser det seg å være en høyere henleggelsesprosent for anmeldelser etter den nye mishandlingsbestemmelsen (straffelovens § 219) enn ved øvrig familievold som er knyttet til de tradisjonelle volds- og trusselbestemmelsene i straffeloven. Rundt 70 prosent av $\S 219$-anmeldelsene ble henlagt i 2010. Rundt 60 prosent av all politianmeldt familievold ble henlagt dette året.

4. Den første delen av straffelovens $§ 219$ lyder slik:

Den som ved å true, tvinge, begrense bevegelsesfriheten til, utøve vold mot eller på annen måte krenke, grovt eller gjentatt mishandler

a) sin tidligere eller nåværende ektefelle eller samboer,

b) sin eller tidligere eller nåværende ektefelles eller samboers slektning i rett nedstigende linje,

c) sin slektning i rett oppstigende linje,

d) noen i sin husstand, eller

e) noen i sin omsorg

straffes med fengsel inntil 4 år. 


\section{Referanser}

Aubert, Vilhelm (1972): Om straffens sosiale funksjon. Oslo. Universitetsforlaget AS.

Bjerknes, Ole Thomas og Ann Kristin Hoff Johansen (2009): Etterforskningsmetoder - en innføring. Bergen. Fagbokforlaget.

Christie, Nils (1977): Konflikt som eiendom. I: Tidsskrift for rettsvitenskap, årgang 89 - 1977.

Christie, Nils (1986): The Ideal Victim. I: Fattah, E.A. (red.) From Crime Policy to Victim Policy. London. Macmillan.

Eriksson, Katarina (1995): Motsträvighet som anomali i rättsväsendet. Poliser och äklagare om kvinnomisshandel. I: Kvinnofrid. Del B. Slutbetänkande av Kvinnovåldskommissionen Statens offentliga utredningar 1995:60. Stockholm. Socialdepartementet.

Grøvdal, Yngvil (2012): En vellykket sak? Kvinner utsatt for mishandling møter strafferettsapparatet. $\mathrm{PhD}$-avhandling innlevert ved Institutt for kriminologi og rettssosiologi. UiO.

Hoyle, Carolyn (1998): Negotiating domestic violence. Police, Criminal Justice, and victims. Oxford. Oxford University Press.

Jacobsson, Katarina (1996): Misshandlade kvinnor - rättsapparatens motsägelsefulla offer. I: Apropå, nr. 3. Stockholm. Brottsförebyggande rådet.

Justis- og politidepartementet (2008): Vendepunkt. Handlingsplan mot vold i ncere relasjoner 2008-2011.

Leer-Salvesen, Paul (1998): Tilgivelse. Oslo. Universitetsforlaget AS.

Loseke, Donileen R. (1992): The battered woman and shelters. The Social Construction of Wife Abuse. State University of New York Press.

Lund, Vibeke (1992): Mishandlede kvinners erfaringer med politiet. I: Forskningsprogram om kvinnemishandling. Rapport nr. 7. NAVF-rapport.

Lundberg, Magnus (2001): Vilja med förhinder. Polisers samtal om kvinnomisshandel. Stockholm. Brutus Östlings Bokförlag Symposium.

Påtaleinstruksen (2003). Forskrift av 28. juni 1985 nr. 1679 om ordningen av påtalemyndigheten. Cappelen Akademiske Forlag.

Rundskriv nr. 3/ 2008. Familievold. Oslo. Riksadvokaten.

Skjørten, Kristin (2002): Lov og rett mot familievold? Oslo. Pax Forlag A/S

Aas, Geir (2009): Politiinngrep i familiekonflikter. En studie av ordenspolitiets arbeid med familiekonflikter/familievoldssaker i Oslo. PhD-avhandling innlevert ved Institutt for kriminologi og rettssosiologi. UiO. 